\title{
CHEMICAL IMMOBILISATION OF TRACE ELEMENTS USING INDUSTRIAL BY-PRODUCTS
}

\author{
Alfreda KASIULIENĖ, Department of Civil, Environmental and Natural Resources Engineering, Luleå University of Technology, \\ Sweden alfreda.kasiuliene@ gmail.com \\ Valdas PAULAUSKAS, Institute of Environment and Ecology, Agriculture Academy, Vytautas Magnus University, K. Donelaičio g. \\ 58, LT-44248 Kaunas, Lithuania valdas.paulauskas@vdu.lt (corresponding author) \\ Ernestas ZALECKAS, Institute of Environment and Ecology, Agriculture Academy, Vytautas Magnus University, Lithuania, K. \\ Donelaičio g. 58, LT-44248 Kaunas, Lithuania ernestas.zaleckas@ vdu.lt
}

\begin{abstract}
Alkaline soil additives used in this study, as cement kiln dust and lime mud, resulted in significant rise of the $\mathrm{pH}$ in contaminated soil and sludge mixtures, while buffering capacity of the sludge appeared to be much stronger than that of the soil. Total concentrations of the investigated trace elements in the tested samples in most cases were above limit values given in Lithuanian environmental normative documents HN 60:2015 and LAND 20:2005; Cd, Zn and Pb concentrations exceeding MPCs by 2-10 times. Nickel, cadmium and copper in the sludge appeared to be the most mobile elements, their EDTA-extractable fraction reaching 30-50\% from the total. The tested industrial by-products in most cases significantly reduced trace element mobility. Immobilizing effect in the contaminated soil was from low to moderate, while impact on the reduction of $\mathrm{Cd}, \mathrm{Pb}, \mathrm{Zn}, \mathrm{Cr}, \mathrm{Ni}, \mathrm{As}, \mathrm{Se}, \mathrm{Hg}$ mobility in the sludge was much stronger. Alkaline treatment was not so effective to reduce mobility of $\mathrm{Cu}$ and As in the soil, but immobilising effect of lime mud on these elements in the sludge was significant. A multivariate data analysis model with two principle components explained $94 \%$ of the data variation. The most distinctive factor, separating samples, was the origin of the two tested metal-rich substrates: contaminated soil and sewage sludge. Contaminated soil could be distinguished by high concentrations of $\mathrm{As}, \mathrm{Tl}, \mathrm{Hg}$ and $\mathrm{Pb}$. Both alkaline treatments on sewage sludge were more effective, thus scores are further from the origin, although, difference between kiln dust and lime mud immobilising effectiveness was not so significant. Application of alkaline amendments: cement kiln dust and lime mud, proved to have strong immobilizing effect on the most of the investigated trace elements, and usage of local by-products for contaminated soil (sludge) remediation purposes could be seen as an environmentally friendly, cost-effective and safe disposal alternative.
\end{abstract}

Keywords: trace elements, contaminated soil, sewage sludge, immobilisation, industrial by-products, alkaline waste

\section{INTRODUCTION}

Trace elements (TE) are chemical elements with a very low concentration (a trace amount) in Earth's crust. In biochemistry, a trace element is a dietary element that is needed in very minute quantities for the proper growth, development, and physiology of the organism. In geochemistry, a trace element is one with a concentration less than $1000 \mathrm{ppm}$ or $0.1 \%$ of a rock's composition. Naturally trace elements are found in Earth's crust and due to weathering, they are dispersed in the environment. All soils contain a full range of TE, but their concentrations usually are very low. Although, TE concentrations differ from soil to soil, toxicity level is seldom reached, because geochemical cycles are very slow. Due to intense anthropogenic activities, these cycles were altered and now soils tend to accumulate TE in concentrations that exceed background values and pose risk to living organisms (Alloway, 2013). Some TE (i. e., micronutrients such as zinc (Zn) or copper $(\mathrm{Cu})$ ) are required to living organisms in small concentrations, but higher doses can be poisonous. Non-essential ones (e.g., arsenic (As), cadmium (Cd), mercury $(\mathrm{Hg})$, lead $(\mathrm{Pb})$ ) become toxic even sooner. Trace elements interact with biomolecules, disrupt essential biological functions and cause toxic effects. Moreover, they have an ability to be transferred from terrestrial ecosystems to the food chain (Kabata-Pendias, 2011; Gall, et al., 2015). There are two basic terms describing how toxic elements move through trophic chain: bioaccumulation and biomagnification. The first one refers to a process when contaminant builds up in tissues if it is adsorbed faster than is removed, and the second one is a process when concentration of a contaminant increases while moving upwards in the food chain (Alexander and Fairbridge, 1999). Plants are a first-hand bond between soil chemical composition and food chain. In general, plants readily uptake TE compounds that are dissolved in the soil solutions in either ionic, chelated or complexed forms. The mobile fraction of many TE behaves like bivalent cations in soil phases and is controlled by dynamic equilibria between solid and liquid phases (Rajakaruna and Boyd, 2008). There are several processes that can influence TE conversion from insoluble to soluble fractions and vice versus: dissolution, sorption, complexation, migration, precipitation, occlusion, diffusion (into minerals), binding by organic substances, absorption and sorption by microbiota (Kabata-Pendias, 2011; Zaidi et al., 2012; Alloway, 2013). Toxic effects in plants induced by TE are related to an element type, speciation, exposure time and concentration. Metal speciation mostly depends on valence degree, particle size and solubility (Tchounwou et al., 2012).

Copyright $\odot 2019$ The Authors. Published by Vytautas Magnus University. This is an open-access article distributed under the terms of the Creative Commons Attribution License (CC BY 4.0), which permits unrestricted use, distribution, and reproduction in any medium, provided the original author and source are credited. 
Scientific literature usually describes toxic effects of the main 8-10 metals and metalloids, including aforementioned $\mathrm{Cu}, \mathrm{Zn}, \mathrm{Cd}, \mathrm{Pb}, \mathrm{Hg}$, As, also chromium $(\mathrm{Cr})$, nickel $(\mathrm{Ni})$, cobalt $(\mathrm{Co})$ or manganese $(\mathrm{Mn})$. Arsenic, for example, was widely used in pesticides, dyes and preservatives in the past. Most of the products containing As compounds now are banned or highly restricted. However, historical soil and water pollution with arsenic persists (Kumpiene et al., 2006). Other trace elements, like platinum-group metals, rare earth metals (or lanthanoids), also such as e.g. tungsten (W), selenium (Se), thallium (Tl), are less investigated, but there is no doubt about their toxicity and danger to the environment. Agency for Toxic Substances and Disease Registry (ATSDR) lists over $25 \mathrm{TE}$ as potentially hazardous to human health and environment. These elements exhibit low total concentration in Earth's crust. Thus, it is difficult to detect them in contaminated media using conventional instrumentation. Sometimes less abundant TE become "emerging contaminants" or "contaminants with emerging concern", meaning that such elements were known to exist, but for which the environmental contamination issues were not fully realized or apprehended (Campbell, 2006; Sauve and Desrosiers, 2014).

Total TE concentrations in the soil are less important when predicting TE availability to plants as well as other living organisms. Trace element mobility in the soil as well as bioavailability are influenced by several factors, such as redox potential, moisture content, OM content, temperature, granulometric composition, and most important $-\mathrm{soil} \mathrm{pH}$ (Alloway, 2013). Unlike many organic pollutants, TE do not undergo biochemical degradation, are very persistent in the environment, and since anthropogenic emissions are higher than the natural ones, TE mobility and bioavailability are altered as well. So, when technogenic input is prevailing, basically all terrestrial components, including soil, surface/ground water, and finally biota are contaminated (Fu and Wang, 2011; Koptsik, 2014; Akcil et al., 2015).

Seeking to reduce TE mobility and bioavailability in-situ chemical stabilisation can be applied. The goal of immobilization is conversion of mobile toxic metal compounds, into more stable and less soluble as well as less toxic metal bearing phases. If TE are incorporated into more stable and less soluble compounds, such as sulphides, phosphates, hydroxides, their mobility and bioavailability will be reduced, and the potential hazards of toxic metals will be lower (Hartley et al., 2004; Yang \& Zhang, 2017). There was always a demand for search of alternative soil remediation methods which are regarded as less intrusive and more costeffective (Hartley \& Leep, 2008). Immobilization treatment could be one of such cost-effective solutions, which is easy to apply, which does not require specific equipment, and no soil ex-situ operation (excavation, transportation, treatment) is needed. Immobilisation can be based on the sorption of contaminants, complex formation or precipitation. Many immobilization techniques have been developed in the past several decades, while soil additives used for immobilisation of TE can be very different, including such as aluminium (Al) and Mn oxides, zero-valent iron and iron compounds, fly ash, cement dust, other alkaline and organic waste materials, geopolymers, biochar, etc (Bertocchi et al., 2005; Seidel et al., 2005; Dobran \& Zagury, 2006; Kumpiene et al., 2006, 2007, 2008; Jeong et al., 2007; Moon et al., 2007; Ruiping et al., 2009; Houben et al., 2013; Bolan et al., 2014; Chen et al., 2016; Tan et al., 2016; Guo et al., 2017; Vu and Gowripalan, 2018).

Aim of this study was to evaluate mobility changes of the selected trace elements (including cadmium, mercury, arsenic, thallium, selenium) in the contaminated soil and sewage sludge after chemical stabilisation using local alkaline industrial by-products.

\section{RESEARCH METHODS}

Contaminated soil (Soil) and sewage sludge (SS) samples were mixed with $20 \%$ of an immobilising additive (calculated on dry weight (DW) basis): cement kiln dust (CKD) or lime mud (LM) according to the scheme provided in Fig. 1. Ultra-pure water was added to all the mixtures to form thick suspension. Mixtures were thoroughly homogenised and left stand still for 2 weeks before elemental analysis. Sludge was sampled at Kaunas wastewater treatment plant after the dewatering stage, composite Soil sample was taken from a brownfield in Kaunas city industrial area, and alkaline waste products CKD and LM originated from local cement and sugar industries, respectively.

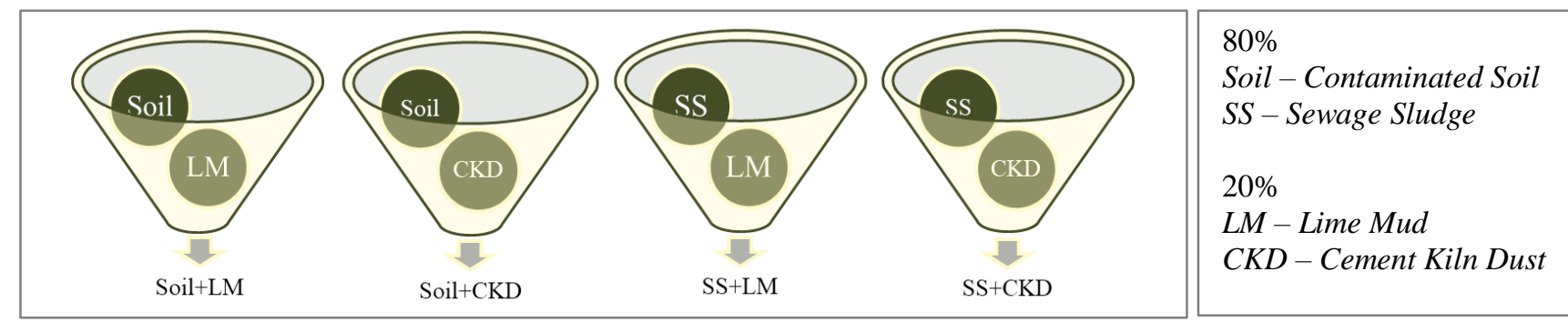

Figure 1. Mixture preparation scheme where trace element mobility in contaminated soil and sewage sludge was attempted to be reduced using CKD and $\mathrm{LM}$

Mixtures were dried at $40^{\circ} \mathrm{C}$, and milled/ground to make it pass through a $2.0 \mathrm{~mm}$ sieve. Total TE concentration in the solids was determined by flame or graphite furnace AAS (Perkin-Elmer 3030) after the digestion with aqua regia, while mobile TE fraction - after extraction with 0.05 molar solution of a strong metal chelating agent diammonium salt of ethylenediaminetetraacetic acid (EDTA). Other mixture properties, as pH, organic matter (OM), moisture and plant nutrient content, were also tested.

All determinations were carried out in triplicates, and results calculated as mean values expressed in $\mathrm{mg} / \mathrm{kg}$ on dry matter (DM) basis. Reagent blanks were used for quality assurance. Significance level was calculated using t-test (two sample analysis assuming unequal variances) when $\mathrm{p}<0.05$. Relative standard deviations for triplicates in all cases were 
below 10\%. Principle component (PC) analysis was used to identify groups of observations within the data set that indicated distinctive differences between analysed sample groups. Multivariate analysis was performed to analyse relationships between measured parameters and different treatments.

\section{RESEARCH RESULTS}

Characterisation of immobilising agents. The goal of chemical stabilization is to convert mobile TE fraction into insoluble and hardly bioavailable chemical species. It was expected that due to alkaline properties, CKD and LM can perform as TE mobility decreasing agents, converting them into insoluble and less toxic hydroxides, carbonates or oxides. Previous research has shown that alkaline waste materials are potentially effective metal immobilisers (Khalid et al., 2017). During the laboratory tests of this study the effectiveness of cement kiln dust and lime mud was judged on the changes of ratio of mobile/immobile fractions in the mixtures that occurred as a result of adding CKD or LM to each tested soil/sludge samples. Both of the selected stabilisers are by-products originating from local industry. CKD is a byproduct collected from kiln exhaust gases during the manufacture of Portland cement while changing the raw mix to a cement clinker at temperatures of $1400-1650^{\circ} \mathrm{C}$. Typically, CKD has approximately one-third of the amount of cement oxides $\left(\mathrm{CaO}, \mathrm{Al}_{2} \mathrm{O}_{3}, \mathrm{SiO}_{2}, \mathrm{Fe}_{2} \mathrm{O}_{3}\right)$ present in Portland cement (Miller \& Azad, 2000). While, there is an abundance of scientific papers on metal immobilization using the final product - Portland cement, the immobilization effect of the discarded CKD is less explored and could contribute to utilisation of this type of waste material. Sugar lime mud is produced after sugar juice is clarified, and is the main solid waste in sugar industry. Its safe disposal always has been the hot topic, as random stacking occupies land and pollutes the air and the underground water (Li et al., 2014). LM is rich in inorganic and organic nutrients, but finds limited use in agriculture as fertilizer or soil conditioner, and the main reason is the insoluble and imbalanced nature of plant nutrients (Elsayed et al., 2008). Lime mud is also rich in calcium compounds and has highly alkaline $\mathrm{pH}$. Scientific literature on LM utilisation as metal pollution stabiliser is scarce. Furthermore, most of the studies deal with LM from pulp and paper mills and red mud. Therefore, study involving LM produced locally could enhance its utilization and offer a TE immobilisation effect.

The available literature indicates that given the proper conditions alkaline waste can be an effective metal immobiliser (Miller \& Azad, 2000; Kumpiene et al., 2008; Khalid et al., 2017). Results of this study showed that mixing resulted in significant rise of the $\mathrm{pH}$ from neutral or slightly acidic up to 10-11 in the sludge mixtures, and up to 11.512.5 in the Soil mixtures. Organic matter content was from 4-5\% in the Soil mixtures and as high as $51 \%$ in the sludge mixtures. Such data indicates on higher buffering capacity of the sludge when compared with the Soil. All mixtures can be characterised as rich in calcium/magnesium oxides (10-15\%), while amount of potassium oxide in all mixtures with kiln dust was 2.2-2.3\%. Mean concentrations of other plant nutrients, as nitrogen and phosphorus (expressed as pentoxide) in the sludge mixtures were 3.6 and $2.7 \%$ respectively.

$\boldsymbol{T E}$ total concentrations. Trace element concentration values, in the tested stabilised mixtures as well as their components, which are determining the level of contamination varied from low to moderate. The range of total concentrations of the selected TE is presented in Table 1.

Table 1. Total TE concentration in the tested samples and maximum permissible TE concentrations in soils according to WHO, FAO and Lithuanian environmental normative documents

\begin{tabular}{|c|c|c|c|c|c|c|c|c|c|}
\hline \multirow{3}{*}{$\begin{array}{c}\text { Elemen } \\
\mathrm{t}\end{array}$} & \multicolumn{9}{|c|}{ Concentration, $\mathrm{mg} / \mathrm{kg}$} \\
\hline & \multirow{2}{*}{$\begin{array}{c}\text { WHO, } \\
\text { FAO } \\
\text { All } \\
\text { soils }\end{array}$} & \multirow{2}{*}{$\begin{array}{c}\text { HN } \\
60: 201 \\
5 \\
\text { All soils }\end{array}$} & \multicolumn{2}{|c|}{ LAND 20:2005 } & \multicolumn{4}{|c|}{$\begin{array}{l}\text { Environmental protection rules for territory contaminated } \\
\text { with chemical compounds management }\end{array}$} & \multirow{2}{*}{$\begin{array}{c}\text { In the tested } \\
\text { Soil, SS, CKD } \\
\text { and LM samples }\end{array}$} \\
\hline & & & $\begin{array}{c}\text { Sand, } \\
\text { sandy loam }\end{array}$ & $\begin{array}{c}\text { Clay, clay } \\
\text { loam }\end{array}$ & $\begin{array}{c}\text { Very sensitive } \\
\text { soil }\end{array}$ & Sensitive soil & $\begin{array}{c}\text { Moderately } \\
\text { sensitive soil }\end{array}$ & $\begin{array}{c}\text { Low } \\
\text { sensitivity soil }\end{array}$ & \\
\hline $\mathrm{Ag}$ & $-*$ & 2 & - & - & 0.25 & 0.5 & 0.75 & 2 & - \\
\hline As & 20 & 20 & - & - & 10 & 20 & 30 & 80 & $0.6-28$ \\
\hline B & - & 50 & - & - & - & - & - & - & - \\
\hline $\mathrm{Ba}$ & - & 700 & - & - & 500 & 700 & 1000 & 1500 & - \\
\hline $\mathrm{Be}$ & - & 10 & - & - & - & - & - & - & - \\
\hline $\mathrm{Cd}$ & 3 & 1.5 & 1 & 1.5 & 0.75 & 1.5 & 2.5 & 3 & $0.75-14$ \\
\hline $\mathrm{Cr}$ & 100 & 80 & 50 & 80 & 50 & 80 & 300 & 600 & $13-136$ \\
\hline Co & 50 & 40 & - & - & 20 & 40 & 60 & 120 & - \\
\hline $\mathrm{Cu}$ & 100 & 75 & 50 & 80 & - & - & - & - & $13-167$ \\
\hline $\mathrm{Fe}$ & 50000 & NG & - & - & - & - & - & - & - \\
\hline $\mathrm{Hg}$ & - & 0.5 & 0.6 & 1 & 0.25 & 0.5 & 0.75 & 1 & $0.2-1.2$ \\
\hline $\mathrm{Mn}$ & 2000 & 1500 & - & - & 1000 & 1500 & 2000 & 10000 & - \\
\hline Mo & - & 5 & - & - & 2.5 & 5 & 7.5 & 15 & - \\
\hline $\mathrm{Ni}$ & 50 & 75 & 50 & 60 & 50 & 75 & 150 & 300 & $16-67$ \\
\hline $\mathrm{Pb}$ & 100 & 80 & 50 & 80 & 50 & 80 & 150 & 500 & $24-169$ \\
\hline $\mathrm{Sb}$ & - & 10 & - & - & 5 & 10 & 15 & 30 & - \\
\hline $\mathrm{Se}$ & 10 & 1.5 & - & - & 0.75 & 1.5 & 2.5 & 4.5 & $0.7-2.1$ \\
\hline $\mathrm{Sn}$ & - & 20 & - & - & 10 & 20 & 30 & 40 & - \\
\hline $\mathrm{U}$ & - & 20 & - & - & 10 & 20 & 30 & 40 & - \\
\hline $\mathrm{V}$ & - & 150 & - & - & 80 & 150 & 300 & 450 & - \\
\hline $\mathrm{Tl}$ & - & - & - & - & - & - & - & - & $4-17$ \\
\hline $\mathrm{Zn}$ & 300 & 300 & 160 & 260 & 75 & 300 & 600 & 1200 & $60-1655$ \\
\hline
\end{tabular}


TE total concentrations were compared with the limit values, given in different Lithuanian, EU and International environmental legislative documents. World Health Organization (WHO) as well as Food and Agricultural Organization (FAO) established maximum permissible concentrations (MPC) for elements in the soil, and many countries have local MPC values based on WHO and FAO guidelines in their national law, which are at the same time in line with European Union (EU) legislation. There are three main documents regarding TE concentrations in soils in Lithuania.

- Lithuanian Hygiene Standard setting MPC for hazardous chemical compounds in the soil (HN 60:2015). Values (Table 1) are applicable to residential and recreational areas as well as agricultural land. The document aims to implement such MPC of hazardous chemical compounds in the soil, which would not influence human health and health of future generations, neither directly nor indirectly, through water, air or plants (Ministry of the Environment, 2004).

- Lithuanian Environmental Regulatory (Normative) Document setting rules for sewage sludge uses for agricultural and land reclamation purposes (LAND 20-2005). It is applicable to the sludges from domestic/municipal and industrial effluent treatment process. The document aims to regulate SS use for agricultural purpose, for energy plant cultivation and for land reclamation in such a manner that no harm would be done to the soil, biota, animals and humans. Permissible concentrations of toxic elements in the soil (Table 1) are given in relation to SS use on agricultural land as fertilizer. If metal concentration in SS exceeds $70 \%$ of MPC for a given element in the soil, then application of $2^{\text {nd }}$ category sewage sludge is prohibited (Ministry of the Environment, 2001).

- Environmental protection rules for territory contaminated with chemical compounds management. Maximum permissible concentrations (Table 1) are given in respect to sensitivity of the territory (Ministry of the Environment, 2008).

One can observe from Table that permissible concentration for some elements differs between different documents and sometimes it is tricky to know which document to follow. It is often a case when a territory manager decides upon lower target values. It was found, that total concentrations of the investigated elements in the tested samples in most cases were above MPC values given both in HN 60:2015 and LAND 20:2005; cadmium, zinc and lead being responsible for the highest level of contamination. Total thallium concentration in the Soil mixtures was the highest (17 mg/kg), but it is not possible to conclude about environmental risk, as no thallium MPC is given in the above discussed normative documents.

$\boldsymbol{T E}$ mobility. Changes of TE mobility in the stabilised Soil and SS mixtures are presented in Fig. 2. The degree of element immobilization was evaluated by analysing the EDTA-leachable fraction in the treated mixtures and comparing with untreated solids. Results of immobilising experiment showed that Soil and SS mixing with alkaline industrial byproducts in most cases significantly reduced TE mobility. Immobilizing effect on trace elements in the Soil was moderate, while $\mathrm{CKD}$ and $\mathrm{LM}$ impact on the reduction of $\mathrm{Cd}, \mathrm{Pb}, \mathrm{Zn}, \mathrm{Cr}, \mathrm{Ni}, \mathrm{As}$, Se, $\mathrm{Hg}$ mobility in the sludge was much stronger. No significant stabilising effect was observed in the case of thallium. Moreover, in several tested Soil samples even an increased mobility after the alkaline treatment was detected for $\mathrm{Cu}$ and $\mathrm{As}$.
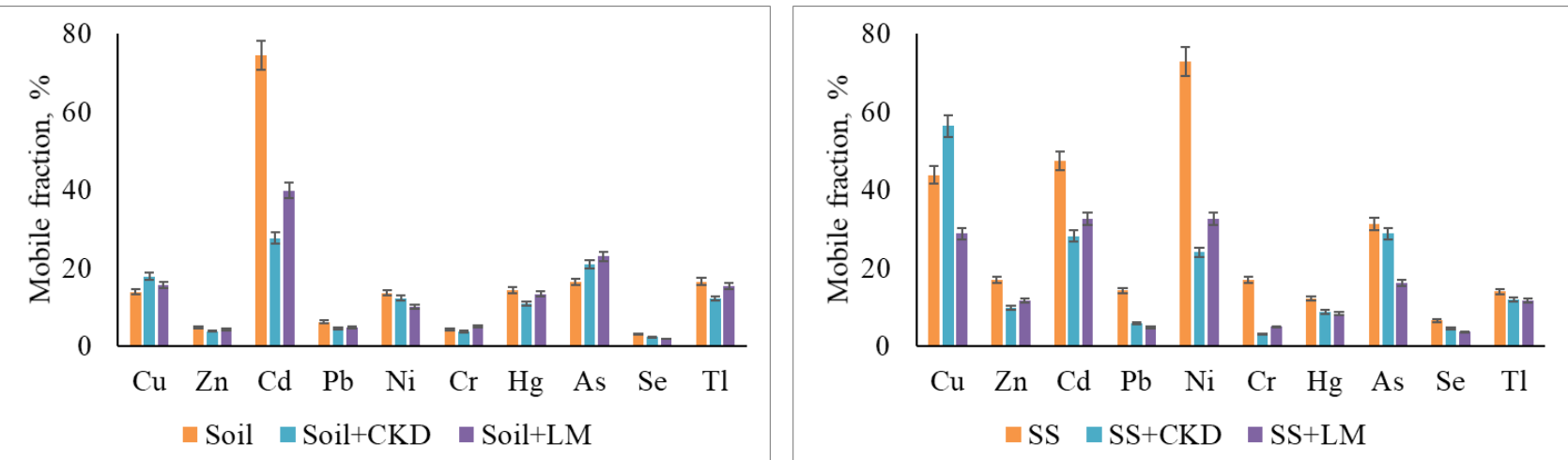

Figure 2. Changes of TE mobility in the stabilised Soil (left) and sewage sludge (right) mixtures

In general, alkaline treatment was able to produce more stable compounds of the majority of the investigated TE in the tested samples and reduce their potential negative impact on the environment and living organisms. The best stabilising results were obtained in the SS mixture with lime mud, where mobility of all the investigated TE was significantly reduced. Important to mention, that lower TE mobility in the growing substrate, as a rule means lower metal bioavailability and finally slower bioaccumulation in plants grown on it (Zeng et al., 2011). Ni, Cd and $\mathrm{Cu}$ in the sludge distinguished as the most mobile elements from the tested ones - mobile fraction reaching 30-50\% of the total concentration. High mobility of the elements in the tested samples might be predetermined by the anthropogenic origin of these contaminants both in the investigated contaminated soil as well as municipal wastewater sludge samples. Alkaline treatment was not so effective to reduce mobility of $\mathrm{Cu}$ and As in the soil, but immobilising effect of lime mud on these elements in the sludge was significant.

Principle component analysis. Most of the results in the multivariate data analysis model are described by two principle components: PC1 and PC2, and together they explain 94\% of the data variation (Fig. 3). The score scatter plot (Fig. 3a) shows how observations from the Soil, SS and their mixtures with LM and CKD are located in the score space with respect to each other. The loading scatter plot (Fig. 3b) is used to explain which variables cause the grouping because 
the averages for each variable were loaded at the same position and correlate with their scores. The most distinctive factor separating samples was the origin of the two main samples: Soil (contaminated soil) or SS. Contaminated soil could be distinguished by high concentrations of $\mathrm{As}, \mathrm{Tl}, \mathrm{Hg}$ and $\mathrm{Pb}$. While $\mathrm{SS}$ contained more of $\mathrm{Cu}, \mathrm{Zn}, \mathrm{Cr}$, and $\mathrm{Cd}$. As it was clear from Fig. 2, alkaline treatment on Soil was not as effective as on SS. This coincides with PCA, because in score scattering plot Soil+LM and Soil+CKD treatments are not far away from its origin - Soil sample.

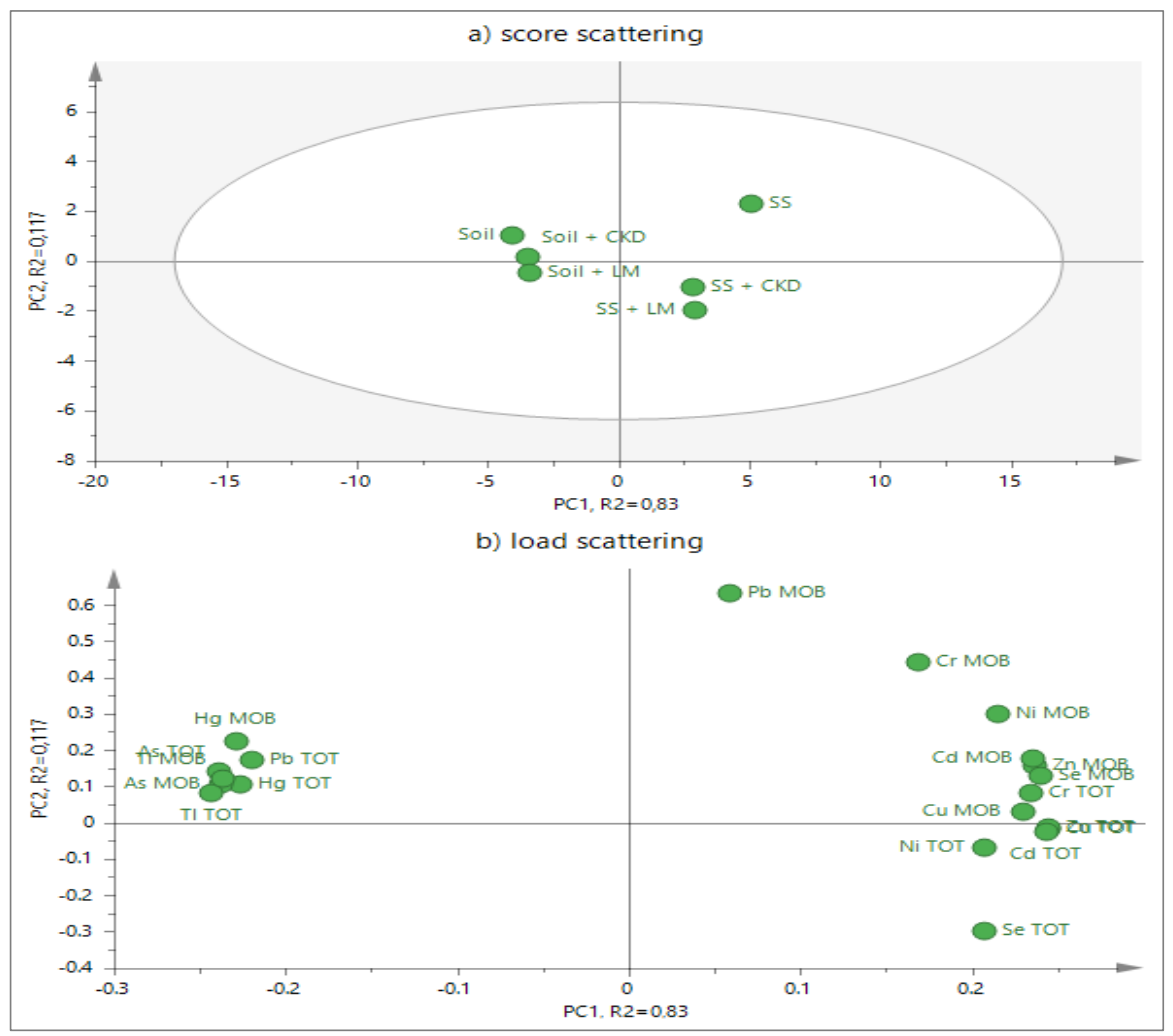

Figure 3. Principle component analysis of TE content in the Soil, sewage sludge and their mixtures with lime mud and cement kiln dust: a) score scatter plot; b) load scatter plot. PC1 and PC2 - principal components 1 and 2, respectively; TOT - total concentrations, MOB - mobile concentrations

Both alkaline treatments on SS were more effective, thus scores are further from the origin (SS), although, difference between CKD and LM immobilising effectiveness was not so significant.

\section{CONCLUSIONS}

- The investigated alkaline additives, as cement kiln dust and lime mud, resulted in significant rise of the $\mathrm{pH}$ of soil and sludge mixtures, while buffering capacity of the sludge appeared to be much stronger than that of the contaminated soil. It was found, that total concentrations of the investigated TE in the tested samples in most cases were above limit values given in LT environmental normative documents (HN 60:2015, LAND 20:2005); Cd, Zn and Pb concentrations exceeding MPCs by 2-10 times. Total thallium concentration in the Soil mixtures was higher than that in the sludge mixtures, but it is not possible to conclude about environmental risk associated with TL, as no limit values for soil Tl levels have been listed in the studied normative documents.

- Nickel, cadmium and copper in the sludge appeared to be the most mobile elements from the tested ones - mobile fraction reaching 30-50\% from their total concentration. Additives of alkaline industrial by-products in most cases significantly reduced trace element mobility. Immobilizing effect in the Soil was from low to moderate, while CKD and $\mathrm{LM}$ impact on the reduction of $\mathrm{Cd}, \mathrm{Pb}, \mathrm{Zn}, \mathrm{Cr}, \mathrm{Ni}, \mathrm{As}, \mathrm{Se}, \mathrm{Hg}$ mobility in the sludge was much stronger. Alkaline treatment was not so effective to reduce mobility of $\mathrm{Cu}$ and $\mathrm{As}$ in the soil, but immobilising effect of lime mud on these elements in the sludge was significant.

- A multivariate data analysis model with two principle components explained $94 \%$ of the data variation. The most distinctive factor, separating samples, was the origin of the two tested metal-rich substrates: contaminated soil and sewage sludge. Contaminated soil could be distinguished by high concentrations of $\mathrm{As}, \mathrm{Tl}, \mathrm{Hg}$ and $\mathrm{Pb}$, while sewage sludge contained more of $\mathrm{Cu}, \mathrm{Zn}, \mathrm{Cr}$, and $\mathrm{Cd}$. Both alkaline treatments on sludge were more effective, thus scores are further from the origin, although, difference between kiln dust and lime mud immobilising effectiveness was not so significant.

- To conclude this study, application of alkaline amendments, cement kiln dust and lime mud, proved to have strong immobilizing effect on most of the investigated TE, and usage of local by-products for contaminated soil (sludge) remediation purposes could be seen as an environmentally friendly, cost-effective and safe disposal alternative. 


\section{REFERENCES}

1. Akcil A., Erust C., Ozdemiroglu S., Fonti V., Beolchini F. 2015. A review of approaches and techniques used in aquatic contaminated sediments: metal removal and stabilization by chemical and biotechnological processes. The Journal of Cleaner Production, Vol. 86, pp. 24-36. https://doi.org/10.1016/j.jclepro.2014.08.009

2. Alexander D. E., Fairbridge R. W. 1999. Bioaccumulation, bioconcentration, biomagnification. Encyclopaedia of environmental science. Dordrecht: Kluwer Academic Publishers.

3. Alloway B. J. (ed.) 2013. Heavy metals in soils. Trace metals and metalloids in soils and their bioavailability. Dordrecht: Springer Science + Business Media. https://doi.org/10.1007/978-94-007-4470-7

4. Bertocchi A.F., Ghiani M., Peretti R., Zucca A. 2005. Red mud and fly-ash for remediation of mine sites contaminated with As, $\mathrm{Cd}, \mathrm{Cu}, \mathrm{Pb}$ and Zn. Journal of Hazardous Materials, Vol. B134, pp. 112-119. https://doi.org/10.1016/j.jhazmat.2005.10.043

5. Bolan N., Kunhikrishnan A., Thangarajan R., Kumpiene J., Park. J., Makino T., Kirkham M. B., Scheckel K. 2014. Remediation of heavy metal(oid) contaminated soils - To mobilize or to immobilize? Journal of Hazardous Materials, Vol. 266, pp. 141-166. https://doi.org/10.1016/j.jhazmat.2013.12.018

6. Campbell P.G.C. 2006. Cadmium - a priority pollutant. Environmental Chemistry, Vol. 3, pp. 387-388. https://doi.org/10.1071/EN06075

7. Chen J., Wang Y., Wang H., Zhou S., Wu H., Lei X. 2016. Detoxification/immobilization of hexavalent chromium using metakaolin-based geopolymer coupled with ferrous chloride. Journal of Environmental Chemical Engineering, Vol. 4(2), pp. 2084-2089. https://doi.org/10.1016/j.jece.2016.03.038

8. Dobran S., Zagury G.J. 2006. Arsenic speciation and mobilization in CCA-contaminated soils: Influence on organic matter content. Science of Total Environment, Vol. 364, pp. 239-250. https://doi.org/10.1016/j.scitotenv.2005.06.006

9. Elsayed M.T., Babiker M.H., Abdelmalik M.E., Mukhtar O.N. 2008. Impact of filter mud applications on the germination of sugarcane and small-seeded plants and on soil and sugarcane nitrogen contents. Bioresource Technology, vol. 99, pp. 4164-4168. https://doi.org/10.1016/j.biortech.2007.08.079

10. Fu F.L., Wang Q. 2011. Removal of heavy metal ions from wastewaters: a review. The Journal of Environmental Management, Vol. 92, pp. 407-418. https://doi.org/10.1016/j.jenvman.2010.11.011

11. Gall J.E., Boyd R.S., Rajakaruna N. 2015. Transfer of heavy metals through terrestrial food webs: a review. Environmental Monitoring and Assessment, Vol. 187, pp. 201-222. https://doi.org/10.1007/s10661-015-4436-3

12. Guo B., Pa, D., Liu B., Volinsky A. A., Fincan M., Du J., Zhang S. 2017. Immobilization mechanism of Pb in fly ash-based geopolymer. Construction and Building Materials, Vol. 134, pp. 123-130. https://doi.org/10.1016/j.conbuildmat.2016.12.139

13. Hartley W., Edwards R., Lepp N.W. 2004. Arsenic and heavy metal mobility in iron oxide-amended contaminated soils as evaluated by short- and long-term leaching tests. Environmental Pollution, Vol. 131, pp. $495-504$. https://doi.org/10.1016/j.envpol.2004.02.017

14. Hartley, W., Lepp, N. W. (2008). Remediation of arsenic contaminated soils by iron-oxide application, evaluated in terms of plant productivity, arsenic and phytotoxic metal uptake. Science of the Total Environment, vol. 390, p. 35-44. https://doi.org/10.1016/j.scitotenv.2007.09.021

15. Houben D., Evrard L., Sonnet P. 2013. Mobility, bioavailability and pH dependent leaching of cadmium, zinc and lead in a contaminated soil amended with biochar. Chemosphere, Vol. 92, pp. 1450-1457. https://doi.org/10.1016/j.chemosphere.2013.03.055

16. Jeong Y., Fan M., Leeuwen J., Belczyk F.J. 2007. Effect of competing solutes on arsenic (V) adsorption using iron and aluminium oxides. Journal of Environmental Sciences, Vol. 19, pp. 910-919. https://doi.org/10.1016/S1001-0742(07)60151-X

17. Kabata-Pendias A. 2011. Trace elements in soils and plants. Boca Raton: Taylor \& Francis Group. https://doi.org/10.1201/b10158

18. Khalid S., Shahid M., Niazi N.K., Murtaza B., Bibi I., Dumat C. 2017. A comparison of technologies for remediation of heavy metal contaminated soils. Journal of Geochemical Exploration, Vol. 182, pp. $247-268$. https://doi.org/10.1016/j.gexplo.2016.11.021

19. Koptsik G.N. 2014. Modern approaches to remediation of heavy metal polluted soils: a review. Eurasian Soil Sci., 47, p. 707-722 https://doi.org/10.1134/S1064229314070072

20. Kumpiene J., Lagerkvist A., Maurice C. 2008. Stabilization of As, $\mathrm{Cr}, \mathrm{Cu}, \mathrm{Pb}$ and $\mathrm{Zn}$ in soil using amendments - A review. Waste Management, Vol. 28, pp. 215-225. https://doi.org/10.1016/j.wasman.2006.12.012

21. Kumpiene J., Montesinos I.C., Lagerkvist A., Maurice C. 2007. Evaluation of the critical factors controlling stability of chromium, copper, arsenic and zinc in iron-treated soil. Chemosphere, Vol. 67, p. $410-417$. https://doi.org/10.1016/j.chemosphere.2006.08.031

22. Kumpiene J., Ore S., Renella G., Mench M., Lagerkvist A., Maurice C. 2006. Assessment of zerovalent iron for stabilization of chromium, copper, and arsenic in soil. Environmental Pollution, Vol. 144, p. 62-69. https://doi.org/10.1016/j.envpol.2006.01.010

23. Li H., Xu W., Yang X., Wu J. 2014. Preparation of Portland cement with sugar filter mud as lime-based raw material. Journal of Cleaner Production, Vol. 66, pp. 107-112. https://doi.org/10.1016/j.jclepro.2013.11.003

24. Miller G.A., Azad S. 2000. Influence of soil type on stabilization with cement kiln dust. Constr and Building Materials, Vol. 14, pp. 89-97. https://doi.org/10.1016/S0950-0618(00)00007-6

25. Ministry of Environment of the Republic of Lithuania (2001). Lithuanian Environmental Regulatory Document LAND $20-2005$. In Lithuanian. Latest access 2019-09-25 at: https://www.e-tar.lt/portal/1t/legalAct/TAR.3536A8337E8A.

26. Ministry of Environment of the Republic of Lithuania. 2004. Lithuanian Hygiene Standard HN 60:2015. In Lithuanian. Latest access 2019-09-25 at: https://www.e-tar.lt/portal/en/legalAct/TAR.633ED152B54A/FIzPxpAIIB. 
27. Ministry of Environment of the Republic of Lithuania (2008). Environmental protection rules for territory contaminated with chemical compounds management. In Lithuanian. Latest access 2018-04-03 at: https://www.e-tar.lt/portal/lt/legalAct/TAR.554 EE563D95B.

28. Moon D.H., Dermatas D. 2006. Arsenic and lead release from fly-ash stabilized/solidified soils under modified semi-dynamic leaching conditions. Journal of Hazardous Materials, Vol. 141, pp. 388-394. https://doi.org/10.1016/j.jhazmat.2006.05.085

29. Rajakaruna N., Boyd R. S. Edaphic factor. Jorgensen, S. E, Fath, E. D. (eds) .2008. General ecology: encyclopaedia of ecology. Amsterdam: Elsevier Science, pp. 1201-1207. https://doi.org/10.1016/B978-008045405-4.00484-5

30. Ruiping L., Lihua S., Jiuhui Q., Guibai L. 2009. Arsenic removal through adsorption, sand filtration and ultra-filtration: In situ precipitated ferric and manganese binary oxides as adsorbents. Desalination, Vol. 249, pp. $1233-1237$. https://doi.org/10.1016/j.desal.2009.06.032

31. Sauve S., Desrosiers M. 2014. A review of what is an emerging contaminant. Chemistry Central Journal, Vol. 8 , pp. 15. https://doi.org/10.1186/1752-153X-8-15

32. Seidel H., Gorsch K., Amstatter K., Mattusch J. 2005. Immobilization of arsenic in a tailings material by ferrous iron treatment. Water Research, Vol. 39, pp. 4073-4082. https://doi.org/10.1016/j.watres.2005.08.001

33. Tan Z., Wang Y., Kasiuliene A., Huang C., Ai P. 2016. Cadmium removal potential by rice straw-derived magnetic biochar. Clean Technologies and Environmental Policy, Vol. 19, pp. 761-774. https://doi.org/10.1007/s10098-016-1264-2

34. Tchounwou P.B., Yedjou C.G., Patlolla A.K., Sutton D.J. 2012. Heavy metals toxicity and the environment. Molecular, Clinical and Environmental Toxicology, Vol. 101, pp. 133-164. https://doi.org/10.1007/978-3-7643-8340-4_6

35. Vu T. H., Gowripalan N. 2018. Mechanism of heavy metal immobilisation using geopolymerization techniques - A review. Journal of Advanced Concrete Technology, Vol. 16, pp.124-135. https://doi.org/10.3151/jact.16.124

36. Yang J., Zhang S. 2017. The mechanisms of heavy metal immobilization by cementitious material treatments and thermal treatments: A review. Journal of Environmental Management, Vol. 193, pp. 410-422. https://doi.org/10.1016/j.jenvman.2017.02.026

37. Zaidi A., Wani P.A., Khan M. S. (eds). 2012. Toxicity of heavy metals to legumes and bioremediation. Verlag Wien: Springer. https://doi.org/10.1007/978-3-7091-0730-0

38. Zeng F., Ali S., Zhang H., Ouyang Y., Qiu B., Wu F., Zhang G. 2011. The influence of pH and organic matter content in paddy soil on heavy metal availability and their uptake by rice plants. Environmental Pollution, Vol.159, pp. 84-91. https://doi.org/10.1016/j.envpol.2010.09.019 